\title{
Cognitive profile in anti-NMDAR encephalitis: Neuropsychological evaluation, rehabilitation, and evolution. A case report
}

\author{
Nuria Montoro-Membila 1, Angel Gómez-Camello 2 , \\ Inmaculada Villegas-Rodríguez ${ }^{2}, \&$ Mónica Triviño-Mosquera ${ }^{3}$ \\ ${ }^{1}$ Neuropsychologist. Mind, Brain and Behaviour Research Center. University of Granada, Spain. \\ 2 Neurologist. Unit of Neurology. Parque Tecnológico de la Salud. Granada, Spain. \\ ${ }^{3}$ Neuropsychologist. San Rafael University Hospital. O. H. San Juan de Dios. Granada, Spain.
}

\begin{abstract}
Encephalitis associated with antibodies against the N-methyl-D-aspartate receptor (i.e., anti-NMDAR encephalitis) is an immune-mediated disorder mainly affecting girls and young women with ovarian teratoma. The clinical picture of the disease progresses from headaches and seizures, psychopathological symptoms (i.e., anxiety, psychosis, or hyperreligiosity), and neuropsychological deficits (i.e., memory, attention, and language disintegration) into a state of agitation, catatonia, dysautonomia (i.e., abnormal movements due to inappropriate muscular activity) and facial dyskinesia. Reports of the neuropsychological profile and evolution, as well as the neuropsychological rehabilitation in anti-NMDAR encephalitis in the literature are scarce. We present the case of a 21 -year-old woman diagnosed with anti-NMDAR encephalitis and we describe the different neuropsychological evaluation tests performed before and after neuropsychological rehabilitation during the acute period. A profile of fronto-subcortical neuropsychological damage was observed with executive functions and emotional regulation affected.
\end{abstract}

Keywords: anti-NMDAR encephalitis, immunodiagnosis, cognitive profile, neuropsychological evaluation, neuropsychological rehabilitation

L'encéphalite avec anticorps antirécepteurs N-méthyl-D-aspartate à médiation immunitaire (c.-à-d., encéphalite anti-NMDAr) touche principalement les filles et les jeunes femmes atteintes de tératome ovarien. Le tableau clinique de la maladie évolue à partir de maux de tête, de crises d'épilepsie, de symptômes psychopathologiques (c.-à-d., anxiété, psychose ou hyperreligiosité) et de déficits neuropsychologiques (c.-à-d., désintégration de la mémoire, de l'attention et du langage), en état d'agitation, de catatonie, de dysautonomie (c.-à-d., mouvements anormaux dus à une activité musculaire inappropriée) et de dyskinésie faciale. Les rapports sur le profil et l'évolution neuropsychologiques et sur la réadaptation neuropsychologique de l'encéphalite anti-NMDAr dans la littérature sont rares. Nous présentons le cas d'une femme de 21 ans atteinte d'encéphalite anti-NMDAr et nous décrivons les différents tests d'évaluation neuropsychologique effectués av ant et après la réadap tation neuropsychologique pendant la phase aiguë. Un profil de lésions neuropsychologiques sous-cortico-frontales a été observé, incluant une altération des fonctions exécutives et de la régu lation émotionnelle.

Mots-clés : encéphalite anti-NMDAr, diagnostic immunitaire, profil cognitif, évaluation neuropsychologique, réadap tation neuropsychologique

Anti-NMDAR encephalitis is a recently identified severe autoimmune disease with a mortality rate between 5 and 7\% (Sansing et al., 2007). This cell membrane receptor exerts critical functions in synaptic transmission and neuronal plasticity (Lau \& Zukin, 2007). This disease does not always have a paraneoplastic origin, that is, symptoms that appear in

The authors report no conflicts of interest.

We thank Dr. Maria Luisa Arnedo Montoro (Professor of

Neuropsychology. Department of Psychobiology, University of

Granada) for her writing assistance.

Correspondence concerning this article should be adressed to / $\mathrm{La}$

correspondance concernant cet article doit être adressée à :

Nuria Montoro-Membil, Mind, Brain and Behaviour Research

Center, University of Granada,

Courriel/e-mail: nuriamontoro@ugr.es locations away from a tumor. Yet, according to the case series study published by Dalmau and colleagues (2007), 90\% of patients diagnosed with anti-NMDAR encephalitis are women with ovarian tumor or teratoma. Furthermore, in $70 \%$ of the cases, the prodromal phase is characterized by a fever, headache, diarrhea, nausea, and vomiting. In subsequent stages, patients exhibit psychopathological symptoms such as anxiety, psychosis, stereotypical, and antisocial behaviors and hyperreligiosity. In advanced stages, signs include agitation, catatonia, seizures, dysautonomia, and facial dyskinesia. Additionally, patients experience a decline in cognitive (i.e., memory, attention, and language disintegration) and executive functions (i.e., working memory, fluency, 
abstract reasoning, flexibility, planning, and problem solving) (Ferioli et al., 2010). However, it is common that some cognitive disorders such as memory deficits are difficult to detect because of reduced verbal production, which can range from speech decline to mutism (Parfene et al., 2016).

Although magnetic resonance imaging may be useful for the diagnosis of viral encephalitis and disseminated acute encephalomyelitis, approximately half of the patients with anti-NMDAR encephalitis do not have magnetic resonance imaging findings or show only mild alterations (Dale et al., 2009; Dalmau et al., 2008; Florance et al., 2009). However, the other half shows an increased signal in the magnetic resonance in the $\mathrm{T} 2$ or FLAIR sequences in the cerebral cortex, especially in both the medial temporal and the cerebellar cortices (Armangue et al., 2016). Abnormalities have also been described less frequently in the corpus callosum or in the brainstem, as well as in the basal ganglia (Rosenfeld \& Dalmau, 2011). Positron emission tomography (PET) with fluorodeoxyglucose could show hypermetabolism in one or both temporal lobes (Dalmau et al., 2008). Therefore, the analysis of cerebrospinal fluid is an important tool for the confirmation of the diagnosis since it is abnormal in $80 \%$ of patients. Findings include moderate lymphocytic pleocytosis (i.e., increase in the level of lymphocyte predominance cells in the cerebrospinal fluid which are often associated with signs of encephalitis), hyperproteinorrachia (i.e., increase in the amount of protein in the cerebrospinal fluid), and, in $60 \%$ of patients, the presence of oligoclonal bands (i.e., proteins called immunoglobulins whose presence indicate inflammation of the central nervous system) (Dalmau et al., 2011).

According to some authors, recovery without sequelae is possible through early diagnosis and management (Herrero-Velázquez et al., 2010). However, this statement should be interpreted with caution, as most studies are focused on neurological sequelae or isolated behavioral disorders. Research on the cognitive profile of anti-NMDA encephalitis is scarce. Some evidence has provided that neuropsychological deficits may cause severe longterm disability, especially in executive functions (Iadisemia et al., 2012) and memory (Finke et al., 2012). Cognitive deficits are not always identified by routine examination, but they are generally discovered by specific evaluations some years after the onset of encephalitis. Symptoms are reported to improve with immune therapy, although neither motor nor cognitive functions retumed to normalcy. Specifically, in the chronic period (i.e., > 12 month from onset), memory and executive functions disturbances have been reported only if neuropsychological rehabilitation was not performed (Nicolle \& Moses, 2018).

These findings reveal the need for further neuropsychological studies on the cognitive and emotional profile, evolution, and response to rehabilitation of patients with anti-NMDAR encephalitis. To provide an insight of these aspects of the disease, we report the case of a patient with anti NMDAR encephalitis who underwent successive neuropsychological evaluations from the subacute phase until completion of neuropsychological rehabilitation.

\section{Case report}

\section{Reason for admission, diagnosis, and treatment}

The Ethics Committee of Biomedical Research of Granada authorized the study in compliance with the Spanish legislation on the protection of personal data (Ministerio de la Presidencia, Relaciones con las Cortes y Memoria Democrática, 1999). The participant signed an informed consent.

We report the case of a 21-year-old woman, a vocational training student, with a history of asymptomatic Crohn's disease and bronchial asthma. The patient presented herself at a specialty hospital in Granada, Spain, in September 2011 and was admitted to the intensive care unit with a fever, headache, decreased level of consciousness, and epileptic status thus requiring sedation and intubation. Wide-spectrum antibiotic therapy was started with acyclovir and antiepileptics. Findings of several tests (cf. Table 1) led to a diagnosis of anti-NMDAR encephalitis. Specific therapy was initiated with corticosteroids and immunoglobulins followed by a bolus of rituximab, a type of antibody, half a month after admission. Cyclophosphamide, a medicine with immunosuppressive properties aimed at preventing the development, growth, or proliferation of malignant tumor cells, was initiated one month after admission. Some oophorectomy was performed for a teratoma detected in the left ovary three months after admission. The patient improved gradually during the intensive care unit stay. After weaning, the patient was transferred to the neurology unit eight months after admission.

In the neurology unit, the patient remained with eyes open, tracked objects, and smiled when spoken to. She did not react to simple commands and could not speak. Upper and lower limbs moved symmetrically and stretch reflexes were normal. The patient had equinus feet and flexor plantar reflex. Other symptoms included tremor, generalized sweating, flexed position, and limb stiffness. The heartbeat was normal. The patient tolerated 


\section{COGNITIVE PROFILE IN ANTI-NMDAR ENCEPHALITIS}

Table 1

Complementary tests

\begin{tabular}{|c|c|c|}
\hline Test & Date & Result \\
\hline Brain CT scan & At admission & Normal. \\
\hline Brain MR scan & At admission & Normal; thickening of left mastoid cells. \\
\hline EEG & At admission & $\begin{array}{l}\text { Non-convulsive status; rhythmic high -amplitude delta activity coinciding with } \\
\text { isolated myoclonus in the four asynchronous limbs, and slow vertical nystagmus; } \\
\text { thirty seconds after the administration of diazepam, this activity disappeared, } \\
\text { followed by a desynchronized, low-amplitude and slow-wave activity. }\end{array}$ \\
\hline Blood tests & At admission & $\begin{array}{l}\text { Glucose, ions, and renal function: normal; liver function: GPT } 57 \text {, GGT } 103 \text {; } \\
\text { cholesterol: } 158 \text {; hemoglobin: } 10.8 \text {; mean corpuscular volume: } 67 \text {; leukocytes: } 3860 \\
\text { (N58\%, L24\%); platelets: } 228000 \text {; vitamin B12 and folic acid: normal; iron: } 20 \text {; } \\
\text { ferritin: } 11 \text {; transferrin: } 410 \text {. }\end{array}$ \\
\hline EKG & At admission & Sinus rhythm without significant alterations. \\
\hline $\mathrm{CSF}$ & At admission & $\begin{array}{l}\text { Leukocytes: } 776 \text { (99\% mononuclear); glucose: } 55 \text {; proteins: } 29 \text {; cultures and PCR } \\
\text { for herpes virus, cryptococcus, and mycobacteria: negative. }\end{array}$ \\
\hline CSF & At admission & $\begin{array}{l}\text { Leukocytes: } 34 \text { (97\% mononuclear); glucose: } 52 \text {; proteins: } 36 \text {; cultures and PCR: } \\
\text { negative; Ac anti-NMDA: positive (not titred). }\end{array}$ \\
\hline
\end{tabular}

Hip and abdominal MR At 2 months $20 \times 18 \mathrm{~mm}$ lesion in left uterine appendage suggestive of teratoma.

Anatomical pathology At 3 months Mature cystic teratoma with marked granulomatous reaction, and ischemic necrosis of the Wilms mamelon.
CSF
At 4 months Positive anti-NMDA: 1/10.
CSF
At 6 months Positive anti-NMDA: 1/100.
EEG
At 8 months Slow base activity, low-amplitude background activity with fast rhythms.
CSF
At 9 months Leukocytes: 3; proteins and glucose: normal; cultures and PCR: negative; pending ac anti-NMDA.

EEG

At 9 months Slightly slow background activity with numerous fast rhythms; improvement with respect to the previous evaluation.

Note $. \mathrm{CSF}=$ cerebrospinal fluid; $\mathrm{CT}=$ computed tomography; $\mathrm{EEG}=$ electroencephalogram; EKG = electrocardiogram; $\mathrm{MR}=$ magnetic resonance.

sedestation position. Oral feeding was initiated after removal of the tracheostomy tube. The patient presented hallucinations and agitation and required quetiapine at low doses.

At discharge, the patient was conscious, oriented in person and space, and partially in time. The patient showed bradypsychia and encoding memory failures. Speech was dysarthric with occasional tachyphrasia,but with correct word finding. She understood simple commands but showed greater difficulty with complex commands. The patient exhibited muscle atrophy with normal sensitivity and bilateral foot drop.
She was transferred to a rehabilitation hospital to continue with physiotherapy and neuropsychological rehabilitation. Readmission was scheduled within six months for the administration of another bolus of cyclophosphamide and follow-up examination, electroencephalography, cognitive evaluation, and a new lumbar puncture.

\section{Neuropsychological evaluation}

Assessment of neuropsychological alterations and their evolution involves a thorough evaluation of the most relevant cognitive and emotional functions. Table 2 (cf. Annexe A) shows the functions assessed, 
the tests used, and outcomes nine to sixteen months after admission. The evaluation was progressively adapted to the characteristics of the patient. Some tests could not be performed during the initial evaluation due to the attention disorders of the patient. The selected tests were also adapted to the needs and availability of the evaluation center. However, the various tests used in this study have been shown to be sensitive in evaluating orientation, attention, praxis, memory, executive functions, as well as emotional processes.

\section{Neuropsychological intervention}

The patient received neuropsychological rehabilitation one hour a day, three days a week, during her income of three months in a rehabilitation hospital. First, basic cognitive functions were addressed including sustained, selective, divided, and alternating attention, inhibitory control, working memory, speech fluency, and abstraction. As the evolution was favorable, since the patient showed fewer difficulties in completing the tasks administered as well as in reaching higher levels of difficulty, rehabilitation of memory, calculation, constructive skills, categorization, reading, writing, and graphomotor skills was started. The family was given some guidelines for irritability and frustration control

Figure 1

Timing and design of neuropsychological rehabilitation during admission in a rehabilitation hospital in the first three months and in the post-discharge phase after three months

\section{More complex cognitive functions and behaviour}

\section{Executive and emotional \\ functions}

Planning and problem solving: cause detection, generating solutions to problems, sequencing of steps to solve tasks and uncertainties, etc.

Social behaviour: identification of emotions, metallization tasks, etc.

Memory: memory games, learning and recall of words, texts, faces, places, etc.

Calculation: arithmetic computations, mathematical problem solving, etc.

Constructive skills: cubes-type games, puzzles, rubicktype games, etc.

Reading and writing: reading of texts, copying, dictation and spontaneous writing, etc.

Irritability and frustration: emotional support, diversion

Basic cognitive 1 and behavioral strategies such as extinction, functions id behavior agreements

Attention: counting tasks, continuous performance tasks, serial subtractions, visual search among distractors, find the differences, "what's wrong" tasks, "what's missing" tasks, etc. Inhibitory control: Stroop-type tasks, Go/no-go-type tasks, Hayling-type tasks, etc.

Working memory: spelling tasks, digit-type tasks, simon game...

Speech fluency: naming semantic category words (e.g., animals, fruits), naming words that begin with a letter (e.g., the letter "p"), "chained words" game, Scrabble-type game, etc.

Abstract reasoning: similarities and differences between words, “odd one out" tasks, syllogisms, incomplete analogies, etc.

\section{Income phase.}

Three months of neuropsychological rehabilitation 1 hour/day (3 days/week)

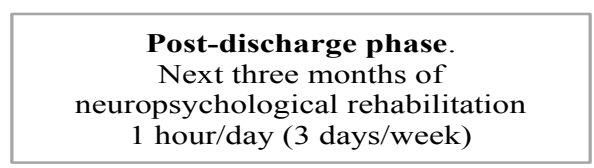

Note. Progression from more basic and prerequisite functions to more complex, executive, and emotional functions, as well as examples of tasks and activities used for this purpose. 


\section{COGNITIVE PROFILE IN ANTI-NMDAR ENCEPHALITIS}

which included emotional support, diversion of attention, and behavioral strategies such as extinction, time-out, and behavior agreements.

Following discharge on August 2012, the patient continued with ambulatory rehabilitation for one hour a day, three days a week, for three more months. Rehabilitation was centered on planning, problemsolving skills, and social behavior. The patient was encouraged to resume her social life and studies. She started studying at home with a private tutor. Further details on the timing and design of the neuropsychological rehabilitation are shown in Figure 1.

\section{Results}

\section{Initial evaluation}

During the subacute phase of the disease, the patient presented severe cognitive impairment with signs of frontal-subcortical damage. Cognitive performance was dramatically below what is expected from someone of her age and level of vocational education. The initial evaluation detected: 1) very deficient sustained, selective, and alternating attention, and an impaired inhibitory control; 2) poor spontaneous language with tendency to mutism; 3) impaired visual and verbal memory, poor learning capacity with high number of perseverations and intrusions, and free recall and recognition deficits; 4) visual perceptual and visuoconstructive deficits; 5) deficits in all executive functions evaluated (i.e., working memory, fluency, abstract reasoning, flexibility, planning, and problem solving); 6) social cognition and emotional function deficits, with highly emotional lability and irritability; and 7) preserved ideomotor and spatial orientation skills.

\section{Neuropsychological evaluation three and six months during and after the intervention}

Follow-up evaluation was performed after three months in the rehabilitation hospital (i.e., during neuropsychological rehabilitation) and after six months in the specialty hospital (i.e., after the intervention finished) where evolution was confirmed to be very satisfactory. After six months, the patient had recovered an almost normal cognitive function with some mild difficulties in visual, spatial, and executive functions. More specifically, the patient showed: 1) susceptibility to interference; 2) altered visual and spatial working memory, visuoconstructive skills, and spatial and visual memory; and 3) word retrieval difficulties. Yet, a significant improvement was observed in the remaining cognitive and emotional skills. At six months, the patient had resumed her social life and studies. Yet, a significant improvement was observed in the remaining cognitive and emotional skills. At six months, the patient had resumed her social life and studies.

\section{Discussion}

NMDAR encephalitis is an autoimmune disease that causes motor and cognitive impairment. Although the disease's clinical profile is well characterized, its cognitive profile and the evolution of cognitive symptoms have not been established yet. Despite the severe cognitive and emotional alterations observed during the acute phase of NMDAR encephalitis, spontaneous recovery is consistently reported in literature. However, a few studies where a more thorough neuropsychological assessment was performed revealed the presence of mild cognitive alterations that persist in the mid and long term. These alterations may prevent a patient's retum to normal life. In fact, cognitive alterations may persist for several years after the onset of the disease (Leypoldt et al., 2013).

This case report includes the typical clinical symptoms of NMDAR encephalitis. The patient presented a severe profile of frontal-subcortical damage, with an impaired gait, psychomotor retardation, higher-function deficit (i.e., attention, speech, memory, and executive skills), and psychopathological alterations including emotional lability and irritability. In contrast with other cases previously reported (Iadisernia et al., 2012), the patient exhibited visuoconstructional and visual perceptual deficits.

These alterations are credited to the action of NMDAR on the nervous system. PET scan revealed anomalies in the temporal lobe and limbic system. Some patients present frontal atrophy and a pattern of diffuse cortical atrophy on PET and RMN (Pillai et al., 2010). Neuropsychological alterations could be associated with these findings. Amnesia could be explained by the interruption of synaptic plasticity mechanisms. These mechanisms are involved in leaming and memory where NMDA receptors in the hippocampus play a crucial role (Dalmau \& Rosenfeld, 2008). Delayed information processing, attention fluctuations, and alterations in speech fluency are signs of frontal-subcortical damage. In this context, early management prevents the exacerbation of cognitive deficits, which are mild at onset, but can interfere with the patient's ability to lead a normal life. Early treatments include neuropsychological rehabilitation.

Cognitive and emotional alterations improved significantly with neuropsychological interventions. These functions returned to almost normal levels earlier than in previous studies where early neuropsychological interventions were not performed 
(Miya et al., 2014). Although further studies are needed, neuropsychological rehabilitation seems to play a key role in achieving almost total recovery, reducing the severity of cognitive symptoms, and preventing persistence over time.

\section{Conclusion}

We described the neuropsychological profile of frontal-subcortical damage in a patient with antiNMDAR encephalitis, which caused substantial cognitive impairment in its acute phase. Cognitive functions improved with neuropsychological rehabilitation. A multidisciplinary approach is crucial to the early diagnosis and successful recovery from NMDAR encephalitis.

\section{Funding}

This project was supported by the Fundación Pública Andaluza para la Investigación Biosanitaria en Andalucía Oriental. Data collection was supported by a grant (reference code 52015) awarded to the first author in the Complejo Hospitalario de Granada.

\section{References}

Armangue, T., Titulaer, M. J., Málaga. I., Bataller, L., Gabilondo, I., Graus, F., \& Dalmau, J. (2016). Pediatric anti-N-methyl-D-aspartate receptor encephalitis-clinical analysis and novel findings in a series of 20 patients. The Joumal of Pediatrics, 162, 850-856. https://doi.org/10.1016/ j.jpeds.2012.10.011

Dale, R. C., Irani, S. R., Brilot, F., Pillai, S., Webster, R., Gill, D., Lang, B., \& Vincent, A. (2009). Nmethyl-D-aspartate receptor antibodies in pediatric dyskinetic encephalitis lethargica. Annals of Neurology, 66, 704-709. https://doi.org/10.1002/ ana. 21807

Dalmau, J. \& Rosenfeld, M. (2008). Paraneoplastic syndromes of the CNS. The Lancet Neurlogy, 7, 327-340. https://doi.org/10.1016/S1474-4422(08) 70060-7

Dalmau, J., Gleichman, A. J., Hughes, E. G., Rossi, J. E., Peng, X., Lai, M., Dessain, S. K., Rosenfeld, M. R., Balice-Gordon, R., \& Lynch, D. R. (2008). Anti -NMDA-receptor encephalitis: Case series and analysis of the effects of antibodies. The Lancet Neurology, 7, 1091-1098. https://doi.org/10.1016/ S1474-4422(08)70224-2

Dalmau, J., Lancaster, E., Martínez-Hernández, E., Rosenfeld, M. R., \& Balice-Gordon, R. (2011). Clinical experience and laboratory investigations in patients with anti-NMDAR encephalitis. The Lancet Neurology, 10, 63-74. https:// doi.org/10.1016/S1474-4422(10)70253-2

Dalmau, J., Tüzün, E., Wu, H.-Y., Masjuan, J., Rossi, J. E., Voloschin, A., Baehring, J. M., Shimazaki,
H., Koide, B., King, D., Mason, W., Sansing, L. H., Dichter, M. A., Rosenfeld, M. R., \& Lynch, D. R. (2007). Paraneoplastic anti-N-methyl-D-aspartate receptor encephalitis associated with ovarian teratoma. Annals of Neurology, 61, 25-36. https:// doi.org/10.1002/ana.21050

Ferioli, S., Dalmau, J., Kobet, C. A., Zhai, Q. J., Broderick, J. P., \& Espay, A. J. (2010). Anti-Nmethyl-D-aspartate receptor encephalitis. Archives of Neurology, 67, 250-251. https://doi.org/10.1001/ archneurol.2009.317

Finke, C., Kopp, U. A., Prüss, H., Dalmau, J., Wandinger, K. P., \& Ploner, C. J. (2012). Cognitive deficits following anti-NMDA receptor encephalitis. Joumal of Neurology, Neurosurgery and Psychiatry, 83, 195-198. http:// dx.doi.org/10.1136/jnnp-2011-300411

Florance, N. R., Davis, R. L., Lam, C., Szperka, C., Zhou, L., Ahmad, S., Campen, C. J., Moss, H., Peter, N., Gleichman, A. J., Glaser, C. A., Lynch, D. R., Rosenfeld, M. R., \& Dalmau, J. (2009). Anti -N-methyl-D-aspartate receptor (NMDAR) encephalitis in children and adolescents. Annals of Neurology, 66, 11-18. https://doi.org/10.1002/ ana. 21756

Herrero-Velázquez, S., Guerrero-Peral, A. L., GámezLeyva, G., Fernández-Buey, M. N., Conde, A., Rodríguez, M., Rojo-Martínez, E., Pascual, J., Fernández-Herranz, M. R., \& Dalmau-Obrador, J. (2010). Encefalitis por anticuerpos contra el receptor NMDA: Descripción de una paciente sin tumor asociado y revisión de la bibliografía. Neurología, 50, 661-666. https://doi.org/10.33588/ rn.5011.2010057

Iadisemia, E., Battaglia, F. M., Vanadia, E., Trapolino, E., Vincent, A., \& Biancheri, R. (2012). Anti-N-methyl-D-aspartate-receptor encephalitis: Cognitive profile in two children. European Joumal of Paediatric Neurology, 16, 79-82. https:// doi.org/10.1016/j.ejpn.2011.09.004

Lau, C. G. \& Zukin, R. S. (2007). NMDA receptor trafficking in synaptic plasticity and neuropsychiatric disorders. Nature Reviews Neuroscience, 8, 413-426. https://doi.org/10.1038/ nrn2153

Leypoldt, F., Gelderblom, M., Schöttle, D., Hoffmann, S., \& Wandinger, K. P. (2013). Recovery from severe frontotemporal dysfunction at 3 years after $\mathrm{N}$-methyl-D-aspartic acid (NMDA) receptor antibody encephalitis. Journal of Clinical Neuroscience, 20, 611-613. https:// doi.org/10.1016j.jocn.2012.03.036.

Ministerio de la Presidencia, Relaciones con las Cortes y Memoria Democrática. (1999). Ley Orgánica de Protección de Datos de Carácter Personal. 
Retrieved from https://www.boe.es/eli/es/ lo/1999/12/13/15

Miya, K., Takahashi, Y., \& Mori, H. (2014). AntiNMDAR autoimmune encephalitis. Brain \& Development, 36, 645-652. https://doi.org/10.1016/ j.braindev.2013.10.005

Nicolle, D. C. M. \& Moses, J. L. (2018). A systematic review of the neuropsychological sequelae of people diagnosed with anti-N-methyl-D-aspartate receptor encephalitis in the acute and chronic phases. A rchives of Clinical Neuropsychology, 33, 964-983. https://doi.org/10.1093/arclin/acy005

Parfene, C., Lipira, C., Gunning, F., \& Gordon-Elliot, J. S. (2016). The neurocognitive profile of anti-Nmethyl-D-aspartate receptor encephalitis patient presenting with neuropsychiatric symptoms. The Journal of Neuropsychiatry and Clinical Neurosciences, 28, 255-256. https:// doi.org/10.1176/appi.neuropsych.16020026

Pillai, S. C., Gill, D., Webster, R., Howman-Giles, R., \& Dale, R. C. (2010). Cortical hypometabolism demonstrated by PET in relapsing NMDA receptor encephalitis. Pediatric Neurology, 43, 217-220. https://doi.org/10.1016/j.pediatmeurol.2010.04.019

Rosenfeld, M. R. \& Dalmau, J. (2011). Anti-NMDAreceptor encephalitis and other synaptic autoimmune disorders. Current Treatment Options in Neurology, 13, 324-332. https://doi.org/10.1007/ s11940-011-0116-y

Sansing, L. H., Tüzün, E., Ko, M. W., Baccon, J., Lynch, D. R., \& Dalmau, J. (2007). A patient with encephalitis associated with NMDA receptor antibodies. Nature Clinical Practice Neurology, 3, 291-296. https://doi.org/10.1038/ncpneuro0493

Received January 7, 2019

Revision received April 4, 2019 Accepted July 28, 2019 
Annexe A

Table 2

Cognitive functions, tests and results from June 2012 to January 2013

Results

Cognitive
functions

\begin{abstract}
At 9 months (specialty hospital)

At 10 months from admission
(rehabilitation hospital) (rehabilitation hospital)
\end{abstract}

At 16 months (specialty hospital)

\begin{tabular}{|c|c|c|c|c|c|c|c|c|c|}
\hline $\begin{array}{l}\text { Cognitive } \\
\text { screening }\end{array}$ & MSSE & $\mathrm{DS}=16 / 30$ & Imp. & NA & & NA & & NA & \\
\hline \multirow[t]{2}{*}{ Orientation } & $\begin{array}{l}\text { In time } \\
\text { (MSSE) }\end{array}$ & $\mathrm{DS}=1 / 5$ & Imp. & $\mathrm{DS}=2 / 5$ & Imp. & $\mathrm{DS}=5 / 5$ & Normal & $\mathrm{DS}=5 / 5$ & Normal \\
\hline & $\begin{array}{l}\text { In space } \\
(\mathrm{MSSE})\end{array}$ & $\mathrm{DS}=5 / 5$ & Normal & $\mathrm{DS}=5 / 5$ & Normal & $\mathrm{DS}=5 / 5$ & Normal & $\mathrm{DS}=5 / 5$ & Normal \\
\hline $\begin{array}{l}\text { Sustained } \\
\text { attention }\end{array}$ & $\begin{array}{c}\text { Strub \& } \\
\text { black } \\
\text { vigilance test } \\
\text { ("A" test) }\end{array}$ & NA & & $\mathrm{DS}=0$ error & Normal & $\mathrm{DS}=0$ error & Normal & NA & \\
\hline $\begin{array}{l}\text { Divided } \\
\text { attention }\end{array}$ & $\begin{array}{c}\text { Color trail, } \\
\text { part B }\end{array}$ & IA & & IA & & $\begin{array}{l}\mathrm{DS}=0 \text { error } \\
\text { Time }=156 \mathrm{~s}\end{array}$ & Imp. & $\begin{array}{l}\mathrm{DS}=2 \text { errors } \\
\text { Time }=103 \mathrm{~s}\end{array}$ & Imp. \\
\hline \multirow[t]{2}{*}{$\begin{array}{l}\text { Selective } \\
\text { attention }\end{array}$} & $\begin{array}{c}\text { Trail making } \\
\text { test, } \\
\text { part A }\end{array}$ & $\begin{array}{l}\mathrm{DS}=2 \text { errors } \\
\text { Time }=155 \mathrm{~s}\end{array}$ & Imp. & NA & & NA & & NA & \\
\hline & $\begin{array}{c}\text { Picture } \\
\text { completion } \\
\text { (WAIS-III) }\end{array}$ & & & IA & & $\mathrm{SS}=8$ & Normal - & $\mathrm{SS}=15$ & Normal+ \\
\hline $\begin{array}{l}\text { Alternating } \\
\text { attention }\end{array}$ & $\begin{array}{l}\text { Alternating } \\
\text { index } \\
\text { (Five digit } \\
\text { test) }\end{array}$ & IA & & IA & & $\mathrm{PC}=30$ & Normal & NA & \\
\hline $\begin{array}{l}\text { Interference and } \\
\text { inhibition }\end{array}$ & $\begin{array}{l}\text { Inhibition } \\
\text { index } \\
\text { (Five digit } \\
\text { test) }\end{array}$ & IA & & IA & & $\mathrm{PC}=10$ & Imp. & NA & \\
\hline $\begin{array}{l}\text { Ideomotor skills } \\
\text { praxis }\end{array}$ & $\begin{array}{c}\text { Ideomotor } \\
\text { (Barcelona } \\
\text { test) }\end{array}$ & $\mathrm{PC}>85$ & Normal & $\mathrm{PC}>85$ & Normal & $\mathrm{PC}>85$ & Normal & $\mathrm{PC}>85$ & Normal \\
\hline \multirow[t]{2}{*}{$\begin{array}{l}\text { Visual-perceptual } \\
\text { skills praxis }\end{array}$} & $\begin{array}{l}\text { Figure copy } \\
\text { (MMSE) }\end{array}$ & $\mathrm{DS}=0 / 1$ & Imp. & NA & & NA & & NA & \\
\hline & $\begin{array}{c}\text { Rey } \\
\text { Complex } \\
\text { figure test }\end{array}$ & & & $\mathrm{PC}=1$ & Very imp. & $\mathrm{PC}=80$ & Normal+ & $\mathrm{PC}=90$ & Normal+ \\
\hline $\begin{array}{l}\text { Visuoconstructive } \\
\text { praxis }\end{array}$ & $\begin{array}{c}\text { Block } \\
\text { Design } \\
\text { (WAIS-III) }\end{array}$ & NA & & IA & & $\mathrm{SS}=4$ & Imp. & $\mathrm{SS}=5$ & Imp. \\
\hline \multirow[t]{2}{*}{$\begin{array}{l}\text { Verbal } \\
\text { memory } \\
\text { learning }\end{array}$} & $\begin{array}{c}\text { Rey auditory } \\
\text { verbal } \\
\text { learning test }\end{array}$ & & & NA & & NA & & NA & \\
\hline & $\begin{array}{l}\text { - Learning } \\
\text { curve }\end{array}$ & $4,6,6,9,8$ & Normal & & & & & & \\
\hline
\end{tabular}


COGNITIVE PROFILE IN ANTI-NMDAR ENCEPHALITIS

\begin{tabular}{|c|c|c|c|c|c|c|c|c|c|}
\hline \multirow[b]{2}{*}{$\begin{array}{l}\text { Cognitive } \\
\text { functions }\end{array}$} & \multirow[b]{2}{*}{ Test } & \multicolumn{8}{|c|}{ Results } \\
\hline & & \multicolumn{2}{|c|}{$\begin{array}{c}\text { At } 9 \text { months } \\
\text { (specialty hospital) }\end{array}$} & \multicolumn{2}{|c|}{$\begin{array}{c}\text { At } 10 \text { months from } \\
\text { admission } \\
\text { (rehabilitation hospital) }\end{array}$} & \multicolumn{2}{|c|}{$\begin{array}{c}\text { At } 13 \text { months from } \\
\text { admission } \\
\text { (rehabilitation hospital) }\end{array}$} & \multicolumn{2}{|c|}{$\begin{array}{c}\text { At } 16 \text { months } \\
\text { (specialty hospital) }\end{array}$} \\
\hline & $\begin{array}{l}\text { - Immediate } \\
\text { memory }\end{array}$ & $\mathrm{DS}=33$ & Imp. & & & & & & \\
\hline & - Intrusions & $\mathrm{DS}=12$ & Imp. & & & & & & \\
\hline & - Perseverations & $\mathrm{DS}=0$ & Normal & & & & & & \\
\hline & $\begin{array}{l}\text { - Delayed } \\
\text { memory }\end{array}$ & $\mathrm{DS}=4$ & Imp. & & & & & & \\
\hline & - Recognition & (50) & Imp. & & & & & & \\
\hline & - False positives & $\mathrm{DS}=0$ & Normal & & & & & & \\
\hline & - False negatives & $\mathrm{DS}=8 / 13$ & Imp. & & & & & & \\
\hline & TAVEC & NA & & & & & & & \\
\hline & - Learning curve & & & $2,7,5,11,7$ & Normal - & $6,5,9,13,15$ & Normal & $7,9,11,10,16$ & Normal \\
\hline & $\begin{array}{l}\text { - Short-term } \\
\text { memory }\end{array}$ & & & $\mathrm{DS}=-2$ & Imp. & $\mathrm{DS}=-1$ & Normal & $\mathrm{DS}=-1$ & Normal \\
\hline & $\begin{array}{c}\text { - Cued short-term } \\
\text { memory }\end{array}$ & & & $\mathrm{DS}=-2$ & Normal - & $\mathrm{DS}=1$ & Normal & $\mathrm{DS}=1$ & Normal \\
\hline & $\begin{array}{l}\text { - Long-term } \\
\text { memory }\end{array}$ & & & $\mathrm{DS}=-2$ & Normal - & $\mathrm{DS}=0$ & Normal & $\mathrm{DS}=0$ & Normal \\
\hline & $\begin{array}{l}\text { - Cued long-term } \\
\text { memory }\end{array}$ & & & $\mathrm{DS}=-5$ & Very imp. & $\mathrm{DS}=0$ & Normal & $\mathrm{DS}=0$ & Normal \\
\hline & $\begin{array}{l}\text { - Intrusions with } \\
\text { cues }\end{array}$ & & & $\mathrm{DS}=5$ & Very imp. & $\mathrm{DS}=-1$ & Normal & $\mathrm{DS}=-1$ & Normal \\
\hline & - Perseverations & & & $\mathrm{DS}=1$ & Normal & $\mathrm{DS}=0$ & Normal & $\mathrm{DS}=0$ & Normal \\
\hline & - Recognition & & & $\mathrm{DS}=-4$ & Imp. & $\mathrm{DS}=0$ & Normal & $\mathrm{DS}=0$ & Normal \\
\hline & - False positives & & & $\mathrm{DS}=1$ & Normal & $\mathrm{DS}=1$ & Normal & $\mathrm{DS}=1$ & Normal \\
\hline $\begin{array}{l}\text { Visual } \\
\text { memory }\end{array}$ & $\begin{array}{l}\text { Rey complex } \\
\text { figure test }\end{array}$ & IA & & IA & & $\mathrm{PC}=1$ & Very imp. & $\mathrm{PC}=1$ & Very imp. \\
\hline $\begin{array}{l}\text { Executive } \\
\text { functions }\end{array}$ & $\begin{array}{l}\text { Motor series } \\
\text { (INECO-FS) }\end{array}$ & NA & & $\mathrm{DS}=0 / 3$ & Imp. & $\mathrm{DS}=3 / 3$ & Normal & $\mathrm{DS}=3 / 3$ & Normal \\
\hline $\begin{array}{l}\text { Motor } \\
\text { planning }\end{array}$ & & & & & & & & & \\
\hline $\begin{array}{l}\text { Sensitivity } \\
\text { to } \\
\text { interference }\end{array}$ & $\begin{array}{l}\text { Conflict index } \\
\text { (INECO-FS) }\end{array}$ & NA & & $\mathrm{DS}=0 / 3$ & Imp. & $\mathrm{DS}=3 / 3$ & Normal & $\mathrm{DS}=3 / 3$ & Normal \\
\hline \multirow[t]{2}{*}{$\begin{array}{l}\text { Inhibitory } \\
\text { control }\end{array}$} & $\begin{array}{l}\text { Go/No-go task } \\
\text { (INECO-FS) }\end{array}$ & NA & & $\mathrm{DS}=0 / 3$ & Imp. & $\mathrm{DS}=3 / 3$ & Normal & $\mathrm{DS}=3 / 3$ & Normal \\
\hline & $\begin{array}{l}\text { Hayling test } \\
\text { (INECO-FS) }\end{array}$ & & & $\mathrm{DS}=3 / 6$ & Imp. & $\mathrm{DS}=6 / 6$ & Normal & $\mathrm{DS}=6 / 6$ & Normal \\
\hline \multirow[t]{3}{*}{$\begin{array}{l}\text { Working } \\
\text { memory }\end{array}$} & $\begin{array}{c}\text { Digits } \\
\text { (WAIS-III) }\end{array}$ & $\mathrm{SS}=1$ & Very imp. & $\mathrm{SS}=3$ & Very imp. & $\mathrm{SS}=7$ & Normal - & $\mathrm{SS}=7$ & Normal - \\
\hline & $\begin{array}{l}\text { Letters and } \\
\text { numbers } \\
\text { (WAIS-III) }\end{array}$ & IA & & IA & & $\mathrm{SS}=8$ & Normal - & NA & \\
\hline & $\begin{array}{l}\text { Spacial location } \\
\text { (WMS-III) }\end{array}$ & IA & & $\mathrm{SS}=2$ & Very imp. & $\mathrm{SS}=5$ & Imp. & $\mathrm{SS}=8$ & Normal - \\
\hline $\begin{array}{l}\text { Semantic } \\
\text { fluency }\end{array}$ & $\begin{array}{l}\text { Animals in } \\
1 \text { minute }\end{array}$ & $\mathrm{DS}=5$ & Imp. & $\mathrm{DS}=8$ & Imp. & $\mathrm{DS}=19$ & Normal & $\mathrm{DS}=18$ & Normal \\
\hline $\begin{array}{l}\text { Phonemic } \\
\text { fluency }\end{array}$ & $\begin{array}{l}\text { 'p' words in } \\
1 \text { minute }\end{array}$ & IA & & IA & & $\mathrm{DS}=8$ & Normal - & $\mathrm{DS}=8$ & Normal - \\
\hline
\end{tabular}




\begin{tabular}{|c|c|c|c|c|c|c|c|}
\hline \multirow{3}{*}{$\begin{array}{l}\text { Cognitive } \\
\text { functions }\end{array}$} & \multirow{3}{*}{$\begin{array}{c}\text { Test } \\
\text { Similarities } \\
\text { (WAIS-III) }\end{array}$} & \multicolumn{6}{|c|}{ Results } \\
\hline & & \multirow{2}{*}{$\begin{array}{l}\text { At } 9 \text { months } \\
\text { (specialty hospital) } \\
\text { NA }\end{array}$} & \multicolumn{2}{|c|}{$\begin{array}{c}\text { At } 10 \text { months from } \\
\text { admission } \\
\text { (rehabilitation hospital) }\end{array}$} & \multicolumn{2}{|c|}{$\begin{array}{c}\text { At } 13 \text { months from } \\
\text { admission } \\
\text { (rehabilitation hospital) }\end{array}$} & $\begin{array}{l}\text { At } 16 \text { months } \\
\text { (specialty hospital) }\end{array}$ \\
\hline & & & $\mathrm{SS}=5$ & Imp. & $\mathrm{SS}=8$ & Normal - & $\mathrm{SS}=8 \quad$ Normal - \\
\hline Planning & $\begin{array}{l}\text { Key search task } \\
\text { (BADS) }\end{array}$ & IA & IA & & Profile $=3$ & Normal & NA \\
\hline \multirow[t]{9}{*}{$\begin{array}{l}\text { Categorization } \\
\text { and flexibility }\end{array}$} & $\begin{array}{l}\text { Flexibility index } \\
\text { (Five digit test) }\end{array}$ & IA & IA & & $\mathrm{PCTL}=20$ & Normal - & NA \\
\hline & $\begin{array}{l}\text { Wisconsin card } \\
\text { sorting test }\end{array}$ & IA & IA & & & & NA \\
\hline & $\begin{array}{l}\text { - Categories } \\
\text { completed }\end{array}$ & & & & $\mathrm{PC}>16$ & Normal & \\
\hline & - Behavior errors & & & & $\mathrm{PC}>16$ & Normal & \\
\hline & - Learning to learn & & & & $\mathrm{PC}>16$ & Normal & \\
\hline & - \% errors & & & & $\mathrm{PC}=53$ & Normal & \\
\hline & - \% perseverations & & & & $\mathrm{PC}=3$ & Imp. & \\
\hline & $\begin{array}{l}\text { - \% perseverative } \\
\text { errors }\end{array}$ & & & & $\mathrm{PC}=12$ & Imp. & \\
\hline & $\begin{array}{c}\text { - } \% \text { non-pereverative } \\
\text { errors }\end{array}$ & & & & $\mathrm{PC}=91$ & Normal & \\
\hline \multirow[t]{3}{*}{$\begin{array}{c}\text { Social } \\
\text { cognition }\end{array}$} & $\begin{array}{l}\text { Comprehension } \\
\text { (WAIS-III) }\end{array}$ & IA & IA & & $\mathrm{SS}=4$ & Imp. & \\
\hline & $\begin{array}{l}\text { Happé strange } \\
\text { stories test }\end{array}$ & IA & IA & & $\mathrm{DS}=2 / 3$ & Normal - & NA \\
\hline & $\begin{array}{l}\text { Faux pas } \\
\text { stories test }\end{array}$ & IA & IA & & $\mathrm{DS}=2 / 3$ & Normal - & NA \\
\hline \multirow[t]{5}{*}{ Emotional area } & NPI & IA & & & & & NA \\
\hline & - Lability & & & Imp. & & Normal & \\
\hline & - Irritability & & & Imp. & & Normal & \\
\hline & $\begin{array}{c}\text { Goldberg } \\
\text { anxiety scale }\end{array}$ & IA & & & & & $\mathrm{PD}=4 / 9$ Normal - \\
\hline & $\begin{array}{c}\text { Goldberg } \\
\text { depression scale }\end{array}$ & IA & & & & & $\mathrm{PD}=4 / 9$ Imp. limit \\
\hline \multicolumn{8}{|c|}{$\begin{array}{l}\text { Note. DS = direct score; IA = Impossible administration; Imp. = Impaired; NA = not administered; Normal }+=\text { Normal } \\
\text { high; Normal - = Normal low; PC = percentile; SS = scaled score. Test abbreviations: BADS = Behavioural Assessment of } \\
\text { Disexecutive Syndrome; INECO-FS = Institute of Cognitive Neurology-Frontal Screening; MMSE = Mini-Mental State } \\
\text { Examination; NPI = Neuropsychiatric Inventory; TAVEC (Test auditivo verbal España-Complutense) }=\text { Spanish- } \\
\text { Complutense Verbal Learning Test; WAIS-III = Wechsler Adult Intelligence Scale, 3rd edition; WMS-III = Wechsler } \\
\text { Memory Scale, 3rd edition. }\end{array}$} \\
\hline
\end{tabular}

